\title{
Barbwire Russian Thistle Seed Germination
}

\author{
JAMES A. YOUNG AND RAYMOND A. EVANS
}

\begin{abstract}
Barbwire Russian thistle (Salsola paulsenii) is the dominant species of severely degraded plant communities in the most arid portions of the Great Basin. The seed germination of this alien annual plant was compared with that of common Russian thistle (S. iberica). In general, the two species of Salsola have similar germination characteristics. However, there were important differences that apparently favor barbwire Russian thistle in arid environments. These advantages were (a) less restrictive afterripening requirements that allow some germination at a broader range of temperature sooner after maturity, (b) more rapid germination at low temperatures during the first 10 days of incubation, and (c) dehiscence of seeds without the necessity of the plants uprooting and tumbling.
\end{abstract}

Barbwire Russian thistle (Salsola paulsenii) has only scant coverage in range management literature because only recently has it been widely recognized in the western United States as a separate species from Russian thistle (S. iberica).

Russian thistle is one of the most widely occurring alien annuals in western North America. This weed was first introduced into the United States in 1873 or 1874 in flax (Linum sp.) seed brought from Russia and sown near Scotland, South Dakota (Stevens 1943; Robbins et al. 1952). Several Canadian provinces and 16 western states of the United States were infested by 1895 . Russian thistle now infests all of the western portion of North America.

Barbwire Russian thistle is native to southeastern Russia and central Asia (Allen 1964). It was probably introduced to the far western United States sometime between 1891-1913 (Beatley 1973). Coville (1893) did not collect barbwire Russian thistle in his extensive botanical explorations on the Death Valley Expedition of 1891. Alice Eastwood, the noted California botanist, collected barbwire Russian thistle near Barstow, California in 1913 (Beatley 1973). Barbwire Russian thistle occurs in California, Nevada, and Utah (Munz 1968; Anonymous 1969).

We do not know exactly when barbwire Russian thistle invaded the Carson Desert of northwestern Nevada. During the 1960's Beatley (1971) established that there were distinct taxonomic entities of Russian thistle in the southern Great Basin. Publication of Beatley's work stimulated our interest and

Authors are range scientists U.S Department of Agriculture Science and Education Administration. Agricultural Research, Renewable Resource Center, Univ. of Nevada. 920 Valley Rd.. Reno 89512.

This study is a contribution from The U.S. Dep. Agr.. SEA. AR.. and the Agr. Exp. Sta.. Univ. of Nevada. Reno. Journal Series No. 423.

Manuscript received August 29.1978 observation in the Carson Desert and we observed what appeared to be the last stages of replacement of Russian thistle by barbwire Russian thistle in the desert rangeland communities of the area. Such replacement has not occurred in many ruderal communities or in areas of irrigated, intensive agriculture.

Previous studies (Young and Evans 1972; Evans and Young 1972) have enumerated many of the seed and seedbed ecology characteristics of Russian thistle. The purpose of this investigation was to conduct similar comparative studies of the seed and seedbed ecology of barbwire Russian thistle.

\section{Methods}

We collected seeds from numerous populations of barbwire Russian thistle growing in degraded plant communities in the northern Carson Desert. Collections were made in November of 1974, 1975, and 1976. Entire plants were pulled before the mature seeds started to fall and after initial post-harvest drying the seeds were hand threshed, cleaned, and stored in paper bags until moisture equilibrium was reached. Further storage, until germination tests were conducted, was at room temperature in the laboratory.

The potential vegetation and soils of the northern Carson Desert have been enumerated by Billings (1945). The area where we collected seeds was first degraded by bands of sheep near the wool and lamb shipping-point at Wadsworth, Nev., and later by cattle on and adjacent to the Pyramid Lake Indian Reservation. The degraded plant communities were invaded first by Russian thistle and during the 1940's by halogeton (Halogeton glomeratus). Extensive control measures for halogeton killed native shrubs in this area.

In all germination tests, four replications of 100 seeds each were arranged in dark gcrminators in a randomized block design. Seeds were placed on nontoxic germination paper in petri dishes for testing. Seeds were considered germinated when the seedlings uncoiled and the hypocotyl arch had risen. Incubation time was 4 weeks with weekly germination counts. In one test, germinating seeds were counted daily.

Germination tests were conducted at the time of seed harvest and $1,3,5$, and 6 months after harvest. Constant incubation temperatures were $-6,-4,-2,0,2,5$ and through $45^{\circ} \mathrm{C}$ and $5^{\circ}-\mathrm{C}$ increments. Altcrnating temperature regimes consisted of 16 hours in each $24-\mathrm{hr}$ period at each lower constant temperature, and $8 \mathrm{hr}$ at all possible higher temperatures. For example $0^{\circ} \mathrm{C}$ was alternated with $2,5,10$, $15,20,25,30,35,40$, and $45^{\circ} \mathrm{C}$, but $40^{\circ} \mathrm{C}$ was alternated with $45^{\circ} \mathrm{C}$ only.

To directly compare the rate of germination of barbwire Russian thistle and Russian thistle we incubated 4-month old seed of both species at $2,5,10,15,20,25,30,35$, and $40^{\circ} \mathrm{C}$ and counted germination daily through 1 week. The Russian thistle seeds were 


\section{Results}

Temperatures for Germination

Barbwire Russian thistle seeds germinated soon after harvest, but the optimum germination [defined as germination not statistically $(P=0.01)$ lower than the maximum] was rather low (Table 1). Seeds germinated at a range of temperatures from -2 to $30^{\circ} \mathrm{C}$. Maximum germination was below $40 \%$ and there was little difference in germination among the cold and cooltemperature regimes.

\section{Afterripening}

The germinability of barbwire Russian thistle seeds increased over the winter, as measured by both the temperature regimes support germination and the percentage of germination at given temperatures (Table 1). This increase in germinability fits the concept of afterripening (Mayer and Poljakoff-Mayber 1963), in which germination increased with storage time after harvest and is relatively independent of storage conditions. By 6 months after harvest the number of temperature regimes that supported germination had almost doubled and average germination had increased from $18 \%$ to $60 \%$ at the temperatures where some germination occurred. The mean of all temperatures, including those where no germination occurred, increased from $8 \%$ to $44 \%$ when the afterripening was satisfied. The average optimum for germination had increased from $23 \%$ to $85 \%$. This increase in germination occurred gradually during the winter after harvest (data for intermediate test not shown).

By early in the spring following maturity, barbwire Russian thistle seeds germinated with no limitations by seedbed temperature. Some germinated at practically all temperature combinations that would prevail in seedbeds in the Artemisia/grasslands (Evans et al. 1970).

\section{Comparison with Russian Thistle}

The pattern of limited germination immediately after harvest and gradually increasing germination during the winter is similar in both barbwire Russian thistle and Russian thistle (Young and Evans 1972). Barbwire Russian thistle seeds generally mature in October. a month earlier than common Russian thistle seeds; however, some overlap in maturation may occur. In December, barbwire Russian thistle seeds germinated in 35\% more temperature regimes (Table 1) than Russian thistle seeds did (Young and Evans 1972). However, overall germination was lower because the additional germination of barbwire Russian thistle was mainly at cold to very cold temperatures where percentage germination was relatively low.

To compare directly the rate of germination of barbwire Russian thistle and Russian thistle we conducted an experiment

Table 2. Greater (+), less (-) or equal (=) germination $(\%)$ of barbwire Russian thistle seeds compared to Russian thistle for 1 through 7 days incubation at 2 through $40^{\circ} \mathrm{C}$. Test run in March 1974, 4 months after harvest. Zeros indicate no germination by either species.

\begin{tabular}{|c|c|c|c|c|c|c|c|}
\hline \multirow{2}{*}{$\begin{array}{l}\text { Incubation } \\
\text { temperature } \\
\left({ }^{\circ} \mathrm{C}\right)\end{array}$} & \multicolumn{7}{|c|}{ Days of incubation } \\
\hline & 1 & 2 & 3 & 4 & 5 & 6 & 7 \\
\hline 2 & 0 & () & $=$ & $=$ & +29 & +25 & +32 \\
\hline 5 & 0 & 0 & +60 & +72 & +76 & +47 & +38 \\
\hline 10 & () & -98 & +91 & +80 & +54 & +28 & +18 \\
\hline 15 & +93 & +96 & +83 & +35 & +32 & +15 & +9 \\
\hline 20 & $+\varphi()$ & +96 & +79 & +49 & +30 & +13 & +10 \\
\hline 25 & +69 & +62 & +44 & +28 & +7 & -22 & -24 \\
\hline 30 & -32 & +78 & +59 & +17 & +9 & +4 & -7 \\
\hline 35 & -17 & +62 & +47 & +54 & +49 & +23 & +29 \\
\hline 40 & $-8 \varphi$ & +40 & +30 & +22 & +5 & +5 & $=$ \\
\hline
\end{tabular}

in March 1974. March is the time of the earliest germination of barbwire Russian thistle in communities of the Carson Desert. Barbwire Russian thistle seeds had a decided advantage in rate of germination at incubation temperatures below $30^{\circ} \mathrm{C}$ for the first 5 to 7 days (Table 2). After the first day the shorter the incubation time during the first week the greater the advantage to barbwire Russian thistle. Wallace et al. (1968) stressed that one of the most important factors in the establishment of Russian thistle was rapid germination. After germination has begun, the radicle must elongate, enter the soil, and start supplying moisture before the seedling desiccates in the typically harsh environment of the seedbeds where this species grows.

\section{Table 3. Emergence (\%) of barbwire Russian thistle seedlings from various planting depths $(\mathrm{cm})$ in a sandy soil and on top of or beneath $0.5 \mathrm{~cm}$ of annual grass litter. ${ }^{\circ}$}

\begin{tabular}{cc}
\hline $\begin{array}{c}\text { Planting depth } \\
\mathrm{cm}\end{array}$ & $\begin{array}{c}\text { Emergence } \\
\%\end{array}$ \\
\hline Bare soil surface & $36 \mathrm{~b}$ \\
0.5 & $93 \mathrm{a}$ \\
1.0 & $90 \mathrm{a}$ \\
2.0 & $90 \mathrm{a}$ \\
3.0 & $82 \mathrm{a}$ \\
4.0 & $32 \mathrm{~b}$ \\
5.0 & $8 \mathrm{c}$ \\
Under $0.5 \mathrm{~cm}$ litter & $93 \mathrm{a}$ \\
On surface of $0.5 \mathrm{~cm}$ litter & $32 \mathrm{~b}$ \\
\hline
\end{tabular}

"Means followed by the same letter are not significantly different at the 0.05 level of probability as determined by Duncan's multiple range test.

\section{Emergence}

Barbwire Russian thistle seeds germinated on the surface of a bare seedbed, but the germination there was low, only slightly more than one-third $(39 \%)$ of that under minimum soil coverage (Table 4). Litter coverage of seeds compensates for lack of soil coverage. The emergence of barbwire Russian thistle in a sandy soil was not significantly $(P=0.01)$ reduced until burial was greater than $3 \mathrm{~cm}$.

\section{Germination under Low Osmotic Potentials}

Russian thistle seeds are noted for relatively high germination under very low osmotic potentials (Young and Evans 1972). Considering the barbwire Russian thistle has replaced Russian thistle in what are generally known as "salt desert" plant communities, one would expect that barbwire Russian thistle could also germinate under greatly reduced osmotic potentials. However, the expected results were not obtaincd when seeds of both species were compared with reduced osmotic potential created with polyethylene glycol (Table 5). When the osmotic

\section{Table 4. Germination (\%) of barbwire Russian thistle and Russian thistle seeds in reduced osmotic potential created with polyethylene glycol or NaCl. ${ }^{\prime}$}

\begin{tabular}{|c|c|c|c|c|}
\hline \multirow[b]{2}{*}{$\begin{array}{c}\text { Osmotic potential } \\
\text { - bars }\end{array}$} & \multicolumn{2}{|c|}{ Barbwire Russian thistle } & \multicolumn{2}{|c|}{ Russian thistle } \\
\hline & $\begin{array}{l}\text { Polyethelene } \\
\text { glycol }\end{array}$ & $\mathrm{NaCl}$ & $\begin{array}{l}\text { Polyethylene } \\
\text { glycol }\end{array}$ & $\mathrm{NaCl}$ \\
\hline 0 & $93 a$ & $93 a$ & $95 a$ & $95 a$ \\
\hline 4 & $58 \mathrm{~cd}$ & $48 c-e$ & $95 a$ & $68 b c$ \\
\hline 6 & $53 c-e$ & $50 \mathrm{c}-\mathrm{e}$ & $89 a b$ & $54 c-e$ \\
\hline 8 & $38 \mathrm{~d}-\mathrm{g}$ & $28 \mathrm{f}-\mathrm{g}$ & $66 \mathrm{bc}$ & $46 c-f$ \\
\hline 12 & $3.3 \mathrm{~d}-\mathrm{g}$ & $20 \mathrm{~g}-\mathrm{h}$ & $64 b c$ & $33 \mathrm{~d}-\mathrm{g}$ \\
\hline 16 & $\operatorname{logh}$ & $2 \mathrm{~b}$ & $55 \mathrm{~cd}$ & $24 \mathrm{f}-\mathrm{h}$ \\
\hline
\end{tabular}


Tab!e 5. Emergence of barbwire Russian thistle seedings with and without potassium nitrate (KNO, $)$ and/or gibberellic acid (GA, $\mathbf{A}_{3}$ added to soil samples collected from the northern Carson Desert and tested in the greenhouse."

Treatments Seedlings $/ \mathrm{m}^{2}$

\section{Control}

$\mathrm{KNO}, 1.0 \mathrm{mM}$

$\mathrm{KNO}_{3,} 0.1 \mathrm{mM}$

$\mathrm{KNO}(0.01 \mathrm{mM}$

GA. $0.27 \mathrm{mM}$

$\mathrm{GA}_{3}(0.56 \mathrm{mM}$

KNO. (0.1 mM

plus $\mathrm{GA}_{: 3} 0.56 \mathrm{mM}$

"Nkams followed by the same letter are not significantly different at the 0.01 level of prohability as determined by Duncan's multiple range test.

potential was reduced with $\mathrm{NaCl}$, germination of the two species was not significantly $(P=0.01)$ different. In interpreting these data, one should be aware that (a) not all soils in the Carson and associated salt deserts have surfaces that are high in soluble salts (Billings 1945) and (b) many studies have shown an inverse relation between germinability under low osmotic potentials and the ability to persist and grow under these conditions (e.g. McGinnies 1960).

\section{Dispersal of seeds}

During the late fall and early winter period when barbwire Russian thistle seeds have fallen, most of the seeds are located under the canopies of the still rooted plants (Fig. 1). This indicates that barbwire Russian thistle seeds disperse without the plants being uprooted and tumbling. In this characteristic barbwire Russian thistle is in sharp contrast to Russian thistle (Evans and Young 1972). Russian thistle plants, in western Nevada, must tumble before the seeds are dispersed. Ecotypes of Russian thistle with self-dispersing seeds have been reported in mid-western United States (personal communication F. Wertman, Control Seed Laboratory, Hopkins, Minn.). When both species grow in the same community, barbwire Russian

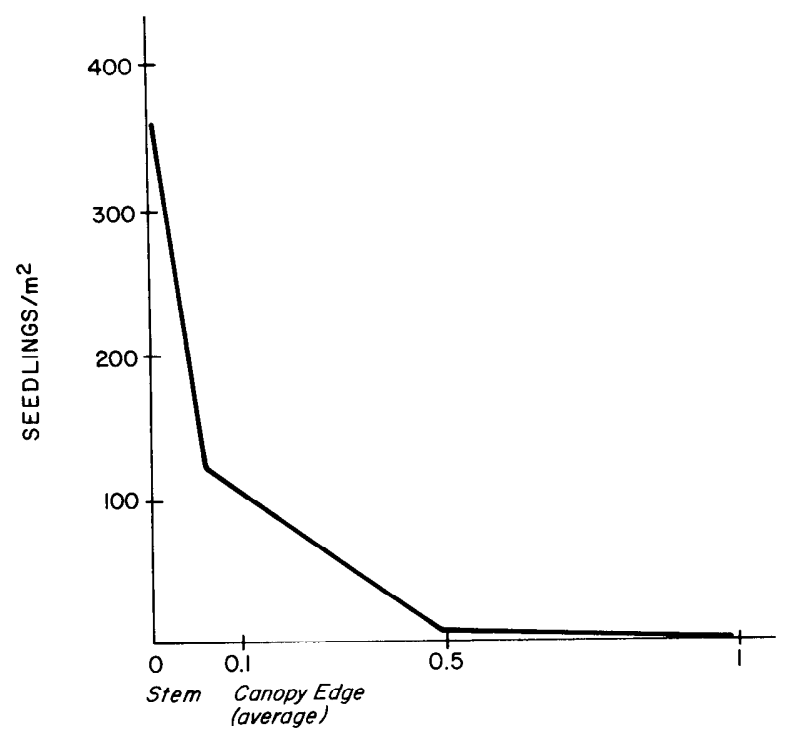

METERS FROM STEM

Fig. 1. Germinable seeds of barbwire Russian thistle per $m^{2}$ of soil at selected distances from the stem of mature plants. Values are means for samples taken in the four cardinal directions and in 2 years (1974 and 1975). Samples were tested in greenhouse. thistle seeds may be dispersed and lying on the soil and available for germination before midwinter storms uproot and tumble Russian thistle plants to disperse their seeds.

\section{Enchancing Germination}

Field observations in the Carson Desert indicated most seeds of barbwire Russian thistle germinated in the early spring. To determine the germinability of the remaining barbwire Russian thistle seeds, we treated bioassay samples from field seedbeds with a source of nitrate (as $\left.\mathrm{KNO}_{3}\right)$ and gibberellin $\left(\mathrm{GA}_{3}\right)$, the two substances known to greatly enhance germination of some seeds (Mayer and Poljakoff-Mayber 1963; Evans and Young 1975). The addition of $0.1 \mathrm{mM} \mathrm{KNO}: 3$ greatly enhanced germination (Table 6). The addition of $\mathrm{GA}_{33}$ also enhanced germination, but not as much. The soils of the Carson Desert are characteristically deficient in available nitrate-N. Any microenvironmental condition that favored nitrification and therefore accumulation of nitrate apparently would favor the germination of barbwire Russian thistle.

\section{Discussion}

Interpretation of the comparative seed ecology of barbwire Russian thistle and Russian thistle is aided by the knowledge that the species have been reported to hybridize freely (Beatley 1973). Where populations of both species integrate. hybrid swarms showing varying degrees of introgression are common. We carefully avoided collected seeds from populations of either species that exhibited great morphologic variability. Despite the occasional hybridization between the species they usually occupy distinct habitats and they have been shown to be physilogically different and morphologically dissimilar (Beatley 1972).

As would be expected of two closely allied species the seed germination of both is relatively similar: but there are subtle and not-so-subtle differences between them. The most important differences that imply an advantage for barbwire Russian thistle are: (a) less restrictive afterripening requirements which allow some germination at more temperatures and sooner after maturity; (b) more rapid germination at low temperatures during the first few days of incubation; and (c) dehiscence of seeds without the necessity of the plants uprooting and tumbling.

The relatively low germination of barbwire Russian thistle under reduced osmotic potentials may be a competitive advantage in disguise. There may be an inverse relation between germinability under osmotic stress and persistence in such environments.

\section{Literature Cited}

Allen, P. 1964. Salsola L. p. 104-107. In: Flora Europaea. Vol. 1. Cambridge Univ. Press.

Anonymous, 1969. New weed menaces desert ranges. Utah Sci. 30:31.

Beatley, J.C. 1971. Ecological and geographic distribution of the vascular plants of southern Nye county and adjacent parts of Clark, Lincoln, and Esmeralda counties, Nevada. Univ. of Calif. Press, Los Angeles. $49 \mathrm{p}$

Beatley, J.C. 1973. Russian-thistle (Salsola) species in Western United States J. Range Manage. 26:225-226.

Billings, W.D. 1945. The plant associations of the Carson Desert Region, Western Nevada. Butler Univ. Bot. Studies. 7:89-123.

Coville, F.V. 1893. Botany of the Death Valley Expedition. Conr. U.S. Nat. Herb. 4. Govt. Printing Office, Washington D.C. 363 p.

Evans, R.A., H.R. Holbo, R.E. Eckert, Jr. and J.A. Young. 1970. Functional environment of downy brome communities in relation to weed control and revegetation. Weed Sci. 18:154-162.

Evans, R.A. and J.A. Young. 1972. Germination and establishment of Salsola in relation to seedbed environment. II. Seed distribution, Gernination and seedling growth of Salsola and microenvironmental monitoring of the seedbed. Agron. J. 64:219-224. 
Evans, R.A. and J.A. Young. 1975. Enhancing germination of dormant seeds of downy brome. Weed Sci. 23:354-357.

Mayer, A.M. and A. Poljakoff-Mayber. 1963. The Germination of Seeds. Pergamon Press, Oxford. $236 \mathrm{p}$.

McGinnies, W.J. 1960. Effects of moisture stress and temperature on germination of six range grasses. Agron. J. 52:159-162.

Munz, P.A. 1968. Supplement to a California Flora. Univ. Calif. Press. Berkeley. 224 p.

Stevens, O.A. 1943. Russian thistle life history and growth. North Dakota Agr. Exp. Sta. Bull. 326:3-20.

Robbins, W.W., A.S. Crafts, and R.N. Raynor. 1952. Weed Control. McGraw Hill Book Co., Inc. New York. 503 p.
Wallace, A., W.A. Rhods, and E.F. Frolich. 1968. Germination behavior of Salsola as influenced by temperature, moisture, depths of planting and gamma radiation. Agron. J. 60:267-268.

Young, J.A. and R.A. Evans. 1972. Germination and establishment of Salsola in relation to seedbed environment. I. Temperature, afterripening, and moisture relations of Salsola seeds as determined by laboratory studies. Agron. J. 64:214-218.

Young, J.A., R.A. Evans, and R.E. Eckert, Jr. 1969. Population dynamics of downy brome. Weed Sci. 17:20-26.

Young, J.A., R.A. Evans, R.O. Gifford, and R.E. Eckert, Jr. 1968. Germination of medusahead in response to temperature and afterripening. Weed Sci. 16:92-95. 